\title{
Effects of Reforms in Nigeria Education Sector: Voices of College Staff/ Counseling Implication
}

\author{
Dr. Anselm Uchenna Anibueze \\ General Studies Unit, Federal University Oye-Ekiti, Ekiti State,Nigeria
}

\begin{abstract}
Four hundred and forty seven (447) Colleges of Education workers in the South East of Nigeria were administered a questionnaire, to determine their perception of the 2006-2007 reform of the colleges. It was found that, although the workers were aware of the intention of the Federal Government in initiating the reform, they noted its poor implementation which caused untold hardship on the staff affected by the exercise. The poor implementation of the reform agenda made the attainment of the objectives of the reform unsustainable and unattainable. Recommendations were made to avoid a repeat of the shortfalls of 2006 reform agenda.
\end{abstract}

\section{Introduction}

Nelson Mandela, a celebrated South African leader said "education is the most powerful weapon which you can use to change the world" and a onetime president of United States of America John F. Kennedy once said "our progress as a nation can be no swifter than our progress in education" and President of Nigeria, Jonathan Goodluck reiterated that "Education is core to whatever we want to do as a nation. Nigeria cannot make much progress towards the attainment of its vision20-2020 unless we strengthen our educational system" Korea, a country with few natural resources, rose from its level of development in the sixties to become a top economic giant by her focus on human development through education. But in Nigeria, an anonymous (2011), said, 'Nigeria's educational sector is in a comatose state or for lack of better words a failed sector. Right from the tertiary, secondary and even primary level, you have a system that does not work. Our so-called graduates even from the ivory towers can hardly read and write properly or express themselves effectively in their chosen fields or on contemporary issues", therefore, the need for a review, reform or paradigm shift.

\section{Concept of Education Reform}

Imoke (2011) said that, "education reforms are representatives of conscious evolution of policy regimes which are capable of bringing significant revolutionary change in the sector. The intent of such reform is to make it more responsive to the needs of the people. It is also important to know that education is a public good one which benefit non-proprietors. An educated workforce is a vital component of a dynamic economy and all its stakeholders both educated and non-educated. According to Cohen (2003), "education reform in any setting is an arrangement by a group of persons or a country to change the "status quo ante, it is the change in policy in education to make better by converting or making improvement from the deficiencies that are in the previous policy. Its main aim is to eradicate the exercise and effects of illegitimate power' Onuigbo (2009) as well said that educational reform is a long process that begins with problem identification, studying, analysis of the existing structure and ending with the evaluation and termination of the programme. It as well involves the development of an alternative policy, experimentation, implementation and feedback. The basic requirement is to meet the needs and aspiration of the people.

Reform has to do with injecting new processes and facilities into an organization, and integrating them to improve the performance of that organization. The provision of excellent service is the major concern of every reform.

Omolewa(2007), stated that educational reforms emanate from the basic conviction that considerable progress can be made in a nation by its people through careful engineering of the educational process. Imoke (2011), emphasized the need for reform when he stated that, "modern societal conditions are reshaping education the world over in a rapid and profound manner. Modern technologies coupled with global economic forces have contributed to an intense and pervasive level of individual, organizational, and international interdependence These new societal dynamics are altering education every bit as much as they are challenging the home life, workplace lifestyle, and political economy of virtually every person in every village, in almost every nation. This point cannot be overemphasized as the world increasingly becomes a global village, driven by a knowledge economy. It is becoming more evident that human capital has become an increasingly valuable asset in the race for industrialization and thus the management of policy concerning this most vital sector has become more important necessitating the need for constant review and reform. These reforms can be broad as was the case in 1954 and the implementation of the whole educational system change from8-6-2-3 to 6-5-2-3 or they can 
be specific to the relevant level such as the setting up of a quality assurance mechanism for higher institutions. Therefore, for an organization to continue to be effective and efficient, it has to be open to reform

Obasanjo (2012), the history of Nigeria runs parallel to the history of Nigerian education, because of the realization by the early nationalists that the country could not develop without a proper grounding in a national education system that can guarantee the production of the desired high quality workforce without which national development is impossible. It is not surprising that the early nationalists were also educators, missionaries, and journalists. Our history as a people is significant for the reform efforts that have been undertaken, with varying degrees of success to get our people to address pressing problems of personal and social development. The current reform agenda and transformation programmes of the Federal Government of Nigeria are part of the historical attempts to direct public attention to necessary changes that must be undertaken collectively and separately to address our daunting challenges in public and private spheres, especially in higher education. More than 50 years ago, the visionaries who founded the University of Nigeria had no doubt about the transformative power of education and its contribution to national development. Unlike any other Nigerian institution of higher learning, the University of Nigeria was established to blaze the trail in the production of a Nigerian workforce equipped with a unique education tailored to address Nigerian problems

The Federal government of Nigeria under the leadership of Chief Olusegun Obasanjo initiated a massive reform of the entire sectors of the economy from banking to education in 1999. In 2006, the government launched a major education reform programme, with a revised vision statement, which led to a comprehensive education sector analysis, and a 10-Year Education Sector Plan. There is also the overcelebrated vision 2020 document with its ambitious projection of making Nigeria "become an emerging economy model, delivering sound education policy and management for public good."The vision of which is to produce effective and efficient economy.

In the education system, one of the reform agendum was targeted at the colleges of education. Some of these colleges have completed some of the core reform activities such as personal audit and rightsizing. It is not clear the direction of subsequent reform activities of these colleges. It has become necessary to know how the workers of these colleges feel about the reform activities already completed. This, it is hoped, will guide further reform activities of the colleges. The Bureau of Public Service Reforms (2006) made provisions in its guidelines for perception surveys that will provide information that ensures stakeholders support for the reforms.

\section{Education Reforms in Nigeria: Historical Perspective.}

Among the fallouts of the agitation for self-rule is to change the educational system in operation in 1954 from 8-6-2-3 system that is 8years primary, 6years secondary, 2years higher school certificate and 3year university to a new system 6-5-2-3 that is, 6years primary, 5years secondary, 2years higher school certificate and 3years university education. Nigeria at that time was regionalized into three; the North, South West and South East regions. Each region enacted her own edict. In 1955, the Western region launched Universal Primary Education (UPE) project. The Eastern region took up the UPE project in 1957. This project was a huge one, the number of enrolment in Eastern schools increased greatly with very few professionals and infrastructure. It was bound to fail especially in the East. However, the success of the scheme was mass education, reduced number of years in primary and secondary schools, the introduction of Higher School Certificates (HSC) to screen candidates for university admission.

In 1959 the colonial government appointed the Ashby Commission; this commission was mandated to investigate into Nigeria's need in the fields of post secondary school certificate and higher education over the next twenty years. The report of the commission as was submitted led to the establishment of the five premier universities; University of Nigeria Nsukka in 1960, Ahmadu Bello University Zaria 1962, University of Lagos 1962, University of Ife 1962 and University of Ibadan that was a university college before she got full recognition as a university in 1962.

The hope in the educational reforms continued to rekindle after independence. The freedom of self-rule Nigeria enjoyed had to match with educational progress. The civil war in Nigeria between 1967-1970 brought in massive upheaval therefore the need for educational reform. Among the policy issues whose formulation and implementation started during this era was the national curriculum review of 1969.

In September 1969 there was a National curriculum conference held in Lagos. Participants at the conference were eager to see Nigeria chart a new course in its educational system. Such a system they reasoned will empower the country towards the path of scientific and technological development. They criticized colonial education system as lacking in vitality and relevance. In short, the conference recommended changes in the system, from 6-5-2-3 system to 6-3-3-4 system; that is 6years primary, 3years junior secondary, 3years senior secondary and 4year university education (Gusau 2008).

The conference recommended; a national policy in education, the federal universal primary education, the take-over of voluntary agencies. The government takeover of schools emerged out of certain social, political, 
economic and strategic (or logistic) factors. Among the fallout of the conference were the decrees that followed from the ruling military regimes;

Decree No.47 of 1971: It was used to establish the industrial training fund. Decree No.29 of 1972; the decree provided for the school year variation from January, December to September July each year.

Decree No.1 of 1974: under this decree the National University Commission was established.

Decree No.12 of 1976: this decree covers the student's loan board.

Decree No.9 of 1977: this decree established the National Boards for Technical Education.

Decree No.11 of 1974: this is called National Youth Service Corps (Amendment) Decree No.11 of 1974

Decree No.46 of 1977: this provided for the Federal Government takeover of all universities in Nigeria

Decree No.2 of 1978: It established the Joint Admissions and Matriculation Board.

Decree No.33 of 1979: It established federal polytechnics and listed under section 5 the function of the polytechnics councils.

Decree No.19 of 1984: this decree was made to abolish all private universities and to barn the establishment of the same.

Decree No.20 of 1984: Establish the miscellaneous offences committed before or during or in anticipation of any examination.

Decree No. 16 of 1985: this was to authorize the federal ministry of education through the National Universities Commission to asses and accredit courses in both federal and state universities.

Decree No.3 of 1986: the decree established the National Commission for Colleges of Education (NCCE).

Decree No.4 of 1986: this was on Federal Colleges of Education.

Decree No.13 of 1986: The decree was on Federal Universities of Technology.

Decree No.20 of 1986: This decree changed school year from October to September to January to December.

Decree No.26 of 1987: The decree was on National library Board (amendment)

Decree No.28 of 1987: It specifically specified the composition of polytechnic councils whose general functions were also set out in section 5 of decree No.33 of 1979.

Decree No.32 of 1987: This was on educational correspondence college's accreditation

Decree No.6 of 1988: It was on University of Ife (Transitional) provisions amendment.

Decree No.7 of 1988: This provided an amendment to the University Teaching Hospital decree.

Decree No. 12 of 1988: It was on student loans board

Decree No.26 of 1988: The decree was used to proscribe and prohibit Academic Staff Union of Universities from participating in trade union activities.

Decree No.31 of 1988: This decree provides amendment to the National Primary Education Commission decree Decree No. 49 of 1988: This provided amendment to the National Universities Commission decree

Decree No. 53 of 1988: It was on Nigerian Educational Research and Developmental Council

Decree of No.33 of 1988: This decree rests in the Joint Admission and Matriculation Board the responsibility for the general control of the conduct of the matriculation examinations for admission into all universities, polytechnics and colleges of education in Nigeria and placement of suitable qualified candidates in the tertiary institutions.

Decree No.40 of 1988: the decree covered the national mathematical centre.

Decree No. 41 of 1989: The decree made provision for the regulation and control of student union activities.

Decree No.17 of 1990: It provided for the National Commission for Mass literacy, Adult and Non-formal Education.

Decree No.36 of 1990: The decree revoked the prescription of academic staff union of universities.

Decree No.37 of 1990: It made miscellaneous provision for federal universities of technology.

Decree No.3 of 1991: It created local government education committee under local government areas. The committee function is fund and management of primary school in the local government areas.

The new policy though widely accepted became unpopular and was widely misunderstood, criticized because it was hastily and poorly implemented. Crises in education started manifesting itself when government went all out to implement the new scheme without adequate planning put in place. This was why Gusau(2008), said "but when political authority picked up the document and shown interest in it, they interpreted it differently. They failed to realize that the document is a proposal produced by academics and interest groups. To put proposal into practice needs a careful planning. This was not done; the far reaching proposal was implemented with a military dispatch which later backfired. The intended result of this beautiful proposal was muddled up and so was never achieved."

However, several other changes were carried out in education sector between 1980-1998 but are not necessarily a reform. Further reforms came on board with Obasanjo civil rule in 1999. The Obasanjo government of 1999 introduced basic education reforms that includes; a process to ensure increase in access to education, the adoption of open and distance learning and the production of employable products of the 
education system, universal basic education was launched to change the total number of years spent in primary from six years to nine, the new education system became 9 years of basic school including 6 years of primary, 3 years of junior secondary, 3 years of senior secondary and 4 years of tertiary education. The 6:3:3:4 systems were gradually transformed into 9:3:4 systems. Another minister in Obasanjo regime ProfessorFabian Osuji who came after Tunde Adeniran re-introduced the higher school certificate to attract the best quality of students into the universities was refused and abandoned rather the minister was removed. Mrs. Obaji who replaced Osuji as minister introduced the post university matriculation examination. The last minister in Obasanjo regime Mrs Oby Ezekwesili initiated a lot of programmes like Operation Reach All Secondary School (ORASS), Tracking Assets for Progress (TAP), Selling of Unity Schools to the public, Public School Community Accountability and Transparency Initiative (PSCATI) and Public Private Partnership (PPP), Merger of Universities, Polytheqnics, Colleges of Education, right sizing and downsizing of these tertiary institutions. This reform received the wildest criticism ever especially the sale of unity schools and the merger of tertiary schools. According to SuleKano (2007), the current reforms being proposed by Ezekwesili were not based on any rich but mere calculated attempt to implement the dictation of the World Bank, which had failed everywhere else. This particular reform is the consolidation of tertiary institutions in Nigeria has raised serious questions than an answer.

\section{Problem of Nigeria Educational Reforms}

Gusau( 2011) criticized the federal government, "from the foregoing, one can discern the inconsistence and confuse nature of the Nigerian educational reforms. In the 70s government took over all the voluntary and mission schools on the pretext of free universal primary education, this reform collapsed in less than a decade. Now the reincarnated Obasanjo administration gambled to sell the federal government unity schools to private capitalists, a complete 360 degree U-turn. Then, what is the essence of educational reforms in Nigeria". The absence of specific agenda for the Nigerian education manifested itself in the tertiary institutions. These institutions especially universities became disorganized when compared with counterparts in other developing countries such as Brazil, South Africa, India etc. Closure of the universities become the norms and so the dismissal of lecturers. Unconducive teaching environment, poor remunerations and threat of dismissal all tend to dampen lecturers morale. The university dons could not continue to tolerate the way and manner federal government is handling education; therefore they take to militancy by resorting to strike actions. Some who had their ways left the country for greener pasture (the brain drain syndrome). It is noted with disgust that among the best brains in the world, Nigeria has a huge chunk and are found everywhere in the world except in Nigeria. Nigerian best brains run away from the country because there are no infrastructural provisions or good governance for them to excel in the country of their origin. Another critic said that there is an ideological decay and confusion over what to do in education sector. Nigeria is running from one goal post to the other in confusion of the kind of education to adopt. From sustainable education to vocational, technical, science, functional to entrepreneurial studies, from 8:6:2:3 of pre-colonial period to $6: 5: 2: 3$ of post-colonial the $6: 3: 3: 4$ of military era to $9: 3: 4$ system of civil government.

The greatest problem in Nigeria education reform is the implementation process. According to Ndu Alice (1992) the problem with Nigeria education is implementation. An anonymous Nigeria critic (2013), said, in his insatiable appetite for committees, he has again exposed his administration's inept handling of the education reform process by appointing a group led by businessman, Aliko Dangote, to transform vocational and technical education in Nigeria. The mere setting up of committees does not translate into good governance; a strong political will to implement policies does... Of all the challenges facing the nation's education, workable recommendations and good reports for policy initiatives are definitely not part of them). Ngozi Okonjo Iwuala (2012),said, among the millions of problems in education sector, "the existing framework for administering education is unclear, as the roles of the various tiers of government within the education system, are not clearly laid out. The fact that education is on the Concurrent List of the 1999 constitution makes its administration complex. Take basic education for example. The recent Steve Oronsaye Committee Report observed that operations of the Universal Basic Education Commission from the federal level are devoid of sufficient input from the schools in the states and local governments where they are expected to maintain good presence and make the most impact. The regulatory system in the sector is largely ineffective, and reflects on the curriculum, especially in many private schools of foreign origin. Pupils in many of these schools are taught little or nothing on Nigeria".

Our Reporter (2012), said, at 52, the Nigerian education sector no doubt has been facing lots of challenges in recent years depending on the strategy adopted towards moving it forward for the desired results. The decision of President Goodluck Jonathan to transform the basic sector of the economy was with clear objectives to improve service delivery and the educational development for the overall development of the nation. Professor Ruqayyatu the current minister of education maintained her earlier One Year Strategy for the Development of the Education Sector now under the 4- Year Strategic Plan for the sector in line with the government's transformation agenda. 
The focus of the 4 year strategic development plan was designed to improve on service delivery and educational performance in the following identified areas:

- Strengthening the Institutional Management of Education

- $\quad$ Standards and Quality Assurance

- Teacher Education and Development

- Access and Equity

- $\quad$ Funding, Partnerships and Resource Utilization

- Technical and Vocational Education and Training TVET

Therefore, the purpose of this study was to determine the perceptions of workers in colleges of education as to the merits and demerits of the 2006 education reform in colleges of education.

\section{Research Questions}

The following research questions guided the study

1 What do the workers think of the reform of the colleges of education?

2 How does the staff think of the implementation process adopted in the reform of the colleges?

3 What really killed the reform agenda in colleges of education of 2006 in Nigeria?

\section{Research Design}

The design was a descriptive survey aimed at finding out the perception of the workers of the reform of the colleges of education.

\section{Subjects}

Four hundred and forty seven (447) workers made up of three hundred and sixteen males and one hundred and thirty one females drawn from colleges of education in the South East of Nigeria constituted the sample.

\section{Instrumentation}

A twenty two items questionnaire consisting of three sections was used for the study. Section A, contained ten (10) items on what the workers think the reform is all about while section B had seven (7) items on the perception of workers on the implementation process of the reform. Section C, had (5) items soliciting information on the success and failure of the reform exercise. The items in the three sections contained statements responded to on a four point scale of; very high extent (with 4 points), high extent (3 points), less extent ( 2 points) and very low extent ( 1 point).

\section{Method of Data Analysis}

Mean score was used to answer the research questions. A bench mark of 2.50 was used in the interpretation of item means. Consequently, an item mean of 2.50 and above indicated acceptance while a mean of less than 2.50 showed rejection.

\section{Results}

The findings were presented in tables according to the research questions

\section{Research Question 1}

What do the workers think of the reform of the colleges of education

Table 1: Mean scores of the workers thinking of what the reform is all about

\begin{tabular}{|l|l|l|l|}
\hline $\mathbf{S} / \mathbf{N}$ & \multicolumn{1}{|c|}{ Item } & $\mathbf{X}$ & Decision \\
\hline 1 & Understood the intention of the federal government o the reform agenda & 2.54 & Accepted \\
\hline 2 & Not a punitive exercise & 2.44 & Rejected \\
\hline 3 & Weeding of the vocal elements among staff of the colleges & 1.87 & Rejected \\
\hline 4 & Those removed were happy & 2.23 & Rejected \\
\hline 5 & I would have accepted the purging in involved & 2.18 & Rejected \\
\hline 6 & The reform exercise would make for a better teacher education in colleges & 1.95 & Rejected \\
\hline 7 & The reform is perceived for the government & 1.95 & Rejected \\
\hline 8 & The reform has a political undertone & 2.42 & Rejected \\
\hline 9 & The reform is just to cut the size of worker and reduce cost & 2.57 & Accepted \\
\hline 10 & $\begin{array}{l}\text { The reform is aimed at satisfying some segment of the society who felt threatened by the } \\
\text { progress made by others }\end{array}$ & 1.95 & Rejected \\
\hline
\end{tabular}


Table 1 shows the workers understood the intentions of the federal government in the reform agenda $(\mathrm{N}=2.54)$. The workers do not believe that the reform has political undertone $(X=2.42)$. The reform is meant to reduce the size of work force and cost (2.57), that the reform was aimed at satisfying some segment of the society was rejected (1.95). The workers see the reform exercise as a punitive exercise by answering no to question posed in negative (2.44). However, the staff sees the exercise as an opportunity for the chief executive to weed off perceived non conformists among staff. Those removed were not happy (2.23). Workers did welcome the exercise (2.18). The reform will neither make for a better teacher education (1.95), nor is it good for the country (1.95). Therefore, the workers do not oppose the idea of the reform of the colleges rather what they opposed was the manner it was carried out.

\section{Research Question 2}

How does the staff think of the implementation process adopted in the reform of the colleges?

Table 2: Mean scores of the workers perception in the implementation process.

\begin{tabular}{|l|l|l|l|}
\hline S/N & \multicolumn{1}{|c|}{ Item } & X & Decision \\
\hline 1 & The reform exercise was carried out in the way it should & 1.33 & Rejected \\
\hline 2 & Those who were removed by the exercise are okay and adjusted. & 1.84 & Rejected \\
\hline 3 & The activities in my college are better as these people are removed & 2.07 & Rejected \\
\hline 4 & The reform can be well funded & 2.51 & Accepted \\
\hline 5 & Those removed were compensated & 2.01 & Rejected \\
\hline 6 & Those removed received all their entitlement & 2.25 & Rejected \\
\hline 7 & The reform exercise was carried out as directed by the federal government & 2.44 & Rejected \\
\hline
\end{tabular}

Table 2 shows that the workers believed that the reform exercise can be adequately funded by the government $(X=2.51)$. In spite of this, those removed have not been compensated $(X=2.01)$, have not received their entitlement $(X=2.25)$, and have not properly adjusted $(X=1.84)$. The reform has not been carried out the way it ought to be done ( $\mathrm{X}=2.23)$ or as directed by the government (2.44). Consequently, the reform exercise so far has not improved performance in the colleges $(X=2.07)$. Therefore, staff felt the reform exercise was not properly implemented.

\section{Research Question 3}

What really killed the reform agenda in colleges of education of 2006 in Nigeria?

Table 3: Mean score of workers perception on the success/failure of 2006 reform exercise

\begin{tabular}{|l|l|l|l|}
\hline $\mathrm{S} / \mathrm{N}$ & \multicolumn{1}{|c|}{ Item } & $\mathrm{X}$ & Decision \\
\hline 1 & The reform exercise is a failure & 2.65 & Accepted \\
\hline 2 & The reform exercise is a huge success & 1.80 & Rejected \\
\hline 3 & The problem with the exercise was implementation & 2.79 & Accepted \\
\hline 4 & The reform exercise was partially carried out & 2.52 & Accepted \\
\hline 5 & The exercise is a failure like other exercises & 2.60 & Accepted \\
\hline
\end{tabular}

Table 3 shows the workers perception of the success or failure of the reform exercise. All the items in table 3 was accepted except question 2 which rejected the idea that the reform exercise was a huge success.

\section{Discussion of the Findings}

Although, the reform has no political or ethnic coloration or undertone, it is not good for Nigeria, probably because of the way it was implemented, Government's good intention notwithstanding. The bane of Nigerian society has always been the poor implementation of projects, programmes, reforms innovations and policies. This agrees with Alice Ndu(1992) in the literature who said that the problem with Nigeria education is implementation. Gusau( 2011) criticized the federal government, "from the foregoing, one can discern the inconsistence and confuse nature of the Nigerian educational reforms. In the 70s government took over all the voluntary and mission schools on the pretext of free universal primary education, this reform collapsed in less than a decade. Now the reincarnated Obasanjo administration gambled to sell the federal government unity schools to private capitalists, a complete 360 degree U-turn. Then, what is the essence of educational reforms in Nigeria". The policy formulations or the design of projects may be done properly; however, when it comes to implementation, it is carelessly or in some cases haphazardly done. This is the case with the reform of colleges of education where up till date the rationalized staff is not adequately compensated for throwing them back into the job market without preparation. Poor management and implementation will always lead to non -attainment of the objectives especially the reform exercise in Nigeria.

\section{Counseling Implication and Recommendation}

1) Government should address implementation problems and processes squarely, because, no reform no matter whatever it is, can work without proper mission to accomplish it.

2) Government should define roles for the stakeholders in education sector 
3) Government should set up an independent committee made up of experts in the education to study implementation mechanism to achieve reasonable results in education reforms

4) Government should maintain equity and fair play in every segment of the education sector; in the sense every segment in the education sector should have codified objectives that are subject to periodical evaluations.

\section{Conclusion}

The workers in colleges of education understand the intentions of the federal government in the reform of the colleges. However, the reform exercise so far has been shown to be unfair to those who were removed from the service of the colleges through rightsizing. This has cast doubt on the mind of workers on the usefulness of the exercise in colleges and why the exercise was fully carried out in colleges of education and not other segments of the education system. The implementation of reforms in colleges of education should be executed in such a manner that all the workers and other stakeholders that are affected would be adequately and timely compensated. They should be paid all their entitlement and be made to adjust properly to avoid loss of confidence from the work force. It is only in this way that any reform exercise will be seen in the light of the vision which is to promote effective and efficient teacher education in Nigeria.

\section{References}

[1]. Bureau of Public Service Reforms (2006) Generic Guideline for the Reform of Ministries, Departments and Agencies (MDAS) in the Federal Civil Service Abuja. The presidency

[2]. Ayooso S. (2011) Nigeria and the Education Sector Reform, http://www.thetidenewsonline.com/2011

[3]. Bello Umar Gusau,( 2008) Educational Reforms in Nigeria: Successive Years of Inconsistencies and Confusions. Http:www.gamji.com/article6000/NEWS7831.htm

[4]. 3 Imoke (2012 ) Reforms in Education: The Roles of Alumnus: A Paper Presented by his Excellency, Senator Liyel Imoke at the University of Nigeria Nsukka. the willnigeria.com

[5]. Goodluck Jonathan in Lyyel Imoke (2012)

[6]. Gusau (2008) Educational Reforms in Nigeria: Successive Years of Inconsistencies and Confusions htt://www.gamji.com/article6000/NEWS7831.htm

[7]. Obasanjo O. (2012) Education and Development at the Graduation Ceremonies of University of Nigeria Nsukka,

[8]. Okonjo-Iweala (2012) Reforming Nigeria's Education System: Paradigm Shift. Keynote Speech at the 2012 Isaac Moghalu Foundation Lecture Civic Center, Victoria Island, Lagos

[9]. Onuigbo A.U. (2009) Education Reforms and the Merger Issues in Colleges of Education Polytechnics, andUniversities: Public Interest . Academic Staff Union Journal Eha-Amufu Chapter Vol. 1 No 1.

[10]. Our Reporter (2012) Nigerian Education at 52: Reforms Under Ruqayaytu Ahmed Rufa'I PUNCH EDITORIAL BOARD (2013) Reform of Vocational Education http://www.punch,com/edtorial April 28 